DOI: https://doi.org/10.24127/ajpm.v10i4.4362

\title{
PENGEMBANGAN DESAIN PEMBELAJARAN STATISTIKA BERBASIS REALISTIC MATHEMATIC EDUCATION (RME)
}

\author{
Silvia $^{1^{*}}$, Ahmad Fauzan ${ }^{2}$, Edwin Musdi ${ }^{3}$, Elita Zusti Jamaan ${ }^{4}$ \\ ${ }^{1 *}$ Universitas Negeri Padang, Indonesia \\ 2,3,4 Universitas Negeri Padang, Indonesia \\ *Corresponding author. Jl. Prof. Dr. Hamka, Air Tawar, Padang, Indonesia \\ E-mail: silviaapril16@ gmail.com $^{1 *}$
}

Received 29 October 2021 2021; Received in revised form 02 December 2021; Accepted 28 December 2021

\begin{abstract}
Abstrak
Statistika merupakan ilmu yang banyak digunakan dalam kehidupan sehari-hari, namun peserta didik masih mengalami kesulitan dalam memahami materi statistika. Peserta didik lebih cenderung dikenalkan dengan penggunaan rumus tanpa melibatkan penemuan konsep dari pengalaman peserta didik sehari-hari. Hal tersebut berdampak pada kemampuan penalaran matematis peserta didik yang masih rendah. Kemampuan penalaran matematis merupakan kemampuan yang harus dimiliki peserta didik dalam belajar matematika. Upaya yang harus dilakukan untuk memaksimalkan pembelajaran di sekolah dengan mendesain pembelajaran berbasis Realistic Mathematics Education (RME) yang diimplementasikan dalam buku guru dan buku siswa. Tujuan dari penelitian ini adalah mendesain alur belajar statistika berbasis RME pada kelas VIII SMP yang valid dan praktis. Metode yang digunakan pada penelitian ini adalah metode Design Research dengan menggunakan dua model pengembangan yaitu model pengembangan Gravemeijer and Cobb dan model Plomp. Model pengembangan Plomp memiliki tiga fase yaitu preliminary, protopyping, dan assesment yang dikombinasikan dengan tiga fase Gravemeijer \& Cobb yaitu preparing for the experiment, conducting the experiment, and retrospective analysis. Subjek penelitian adalah siswa kelas VIII SMPN 2 Siak. Teknik analisis data dalam penelitian ini, data kuantitatif didapatkan melalui angket, sedangkan data kualitatif dikumpulkan melalui observasi, wawancara dan catatan lapangan serta soal tes akhir. Hasil dari penelitian ini adalah peserta didik mampu menemukan konsep statistika dari buku peserta didik berbasis RME. Hasil penelitian menenjukkan desain pembelajaran statistika berbasis RME untuk meningkatkan kemampuan penalaran matematis sudah valid dan praktis.
\end{abstract}

Kata Kunci: HLT; penalaran matematis; realistic mathematics education; statistika.

\begin{abstract}
Statistics is a science that is widely used in everyday life, but students still have difficulty understanding statistical material. Students are more likely to introduced tothe use of formulas without involving the discovery of concepts from the daily experiences of students. This has an impact on students' mathematical reasoning abilities which are still low. Mathematical reasoning ability is an ability that must be possessed by students in learning mathematics. Efforts must be made to maximize learning in schools by designing learning based on Realistic Mathematics Education which is implemented in teacher and student books. The purpose of this research is to design a statistical learning flow based on RME for class 8 Junior High School that is valid and practical. The method used in this study is the Design Research method using two development models, namely the Gravemeijer and Cobb development model and the Plomp model. The Plomp development model has three phases, namely preliminary, protopyping, and assessment combined with three phases of Gravemeijer \& Cobb, namely preparing for the experiment, conducting the experiment, and retrospective analysis. The subject of the study was a student of class 8 Junior High School 2 Siak. Data analysis techniques in this study, quantitative data obtained through questionnaires, while qualitative data is collected through observations, interviews and field records and final test questions. The result of this study is that students are able to find statistical concepts from RME-based student books. The results of the study show that the RMEbased statistical learning design to improve mathematical reasoning skills is valid and practical.
\end{abstract}

Keyword: HLT; mathematical reasoning ability; realistic mathematics education; statistic. 
DOI: https://doi.org/10.24127/ajpm.v10i4.4362

\section{PENDAHULUAN}

Statistika merupakan ilmu yang banyak digunakan dalam kehidupan sehari-hari. Statistika merupakan topik dalam pelajaran matematika yang harus dipelajari oleh peserta didik. Ilmu statistika banyak digunakan oleh perusahaan besar untuk mendapatkan hasil terbaik bagi perusahaan mereka (Nisa et al., 2019). Statistika merupakan topik matematika yang harus dipelajari oleh peserta didik di sekolah. Menurut (Maryati, 2017), penalaran statistis merupakan kemam-puan untuk memahami informasi-informasi yang ada dalam kehidupan keseharian berdasarkan data statistik, kemampuan untuk menjawab permasa-lahan dengan baik berdasarkan data yang ada dengan cara yang berbeda dan memperoleh hasil yang tidak jauh berbeda.

Meskipun banyak aplikasinya dalam kehidupan sehari-hari, masih banyak peserta didik yang mengalami kesulitan pada materi statistika. Beberapa penelitian menunjukkan bahwa peserta didik mengalami kesulitan dalam menganalisis data diagram lingkaran, batang dan membacanya (Masthura et al., 2016), peserta didik juga banyak mengalami kesalahan dalam menentukan nilai rata-rata dan menganalisis suatu data (Dewi et al., 2020), Hal ini terjadi karena peserta didik tidak diberi kesempatan untuk memahami kegunaan mempelajari statistika dan belum dibiasakan dengan bernalar statistika (R. M. Sari et al., 2017).

Didukung dari hasil pengamatan lapangan, pembelajaran statistika dimulai dengan memberikan sekumpulan data dan memberikan rumus-rumus, peserta didik tidak dibiasakan menemukan konsep-konsep matematika dengan sendirinya, guru lebih cenderung memberikan konsep yang ada. Sebagian besar guru matematika berkeyakinan pendekatan mekanistik ini adalah cara terbaik untuk pembelajaran matematika (Smith et al., 2011), (Rangkuti, 2015), \& (Fauzan \& Yerizon, 2013).

Akibat dari bentuk proses belajar mengajar statistika yang diterapkan akan berdampak pada kemampuan peserta didik. Hal tersebut membuat peserta didik tidak terbisa menggunakan penalarannya dalam menyelesaikan permasalahan statistika Hasil-hasil studi TIMSS mengungkap bahwa peserta didik Indonesia masih lemah pada aspek penalaran dan pemecahan masalah (Mullis et al., 2012). Kondisi yang sama juga ditemukan pada hasil-hasil studi PISA yang menunjukkan bahwa rangking Indonesia selalu berada pada $10 \%$ terbawah (Stacey, 2011) \& (OECD, 2015). Menurut (Maryati \& Nanang Priatna, 2017), Kemampuan penalaran matematis peserta didik pada topik statistika juga rendah, sedangkan statistika merupakan cabang ilmu yang banyak digunakan dalam kehidupan sehari-hari.

Berdasarkan permasalahan diatas diharapkan peserta didik diberi kesempatan dan dibimbing ke dalam situasi untuk menemukan konsep dengan cara mereka sendiri agar pembelajaran lebih bermakna (Wijaya, 2012). Peranan guru dapat dimaksimalkan dengan mengembangkan desain pembelajaran. Desain yang dimaksud Hypotetical Learning Trajectory. HLT dapat membantu untuk menjembatani pekerjaan dan mendukung pencapaian belajar dan juga dapat membantu guru mengevaluasi dan memikirkan ulang pengajaran, yang memungkinkan sebelum mereka mulai mengajar (Andrews-Larson et al., 2017), (Daro et al., 2011), \& (Cárcamo Bahamonde et al., 2017). Kemudian 
juga didukung oleh (Laurens et al., 2017) yang mengatakan bahwa peningkatan kognitif peserta didik yang diajarkan melalui RME lebih baik dibanding dengan dengan pembelajaran biasa. HLT yang dirancang didasarkan pada tiga prinsip utama RME untuk instruksional yang dirancang, yaitu reinvention yang dipandu melalui mathematization progresif, fenomenologi didaktis (K Gravemeijer, 2010).

Dari permasalahan diatas, tujuan dari penelitian ini adalah untuk mengembangkan desain pembelajaran statistika berbasis realistic mathematic education (RME) pada kelas VIII SMP yang valid dan praktis.

\section{METODE PENELITIAN}

Jenis penelitian ini merupakan penelitian desain (design research) yang menggunakan dua model pengembangan yaitu model Gravemeijer \& Cobb dan model Plomp. Penggabungan dua model pengembangan dikarenakan pada model Gravemeijer \& Cobb, dalam pengembangan alur pembelajaran tahap awal hanya mengarah pada kajian literatur dan juga produk yang dikembangkan tidak mempertimbangkan untuk divalidasi. Produk berupa bahan ajar membutuhkan kriteria acuan yaitu validitas dan praktikalitas, sehingga diperlukan model pengembangan yang sesuai. Karena itu dipilih model Plomp, dengan alasan saling menguatkan dan pada tahap tertentu cocok untuk dikombinasikan.

Pada fase preparing for the experiment yaitu tahap pertama model Gravemeijer dan Cobb hanya mengkaji ulang tentang literatur yang terkait dengan penemuan konsep dan memperjelas maksud teoritis, namun tidak terlalu memperhatikan informasi terkait dengan kebutuhan, kurikulum, karakteristik peserta didik. Mengingat alur pembelajaran yang dirancang pada penelitian ini diimplementasi pada bahan ajar, sehingga melalui model Plomp akan dilakukan beberapa analisis kebutuhan sebagai dasar perancangan alur pembelajaran yang sesuai dengan model Plomp pada fase Preliminary research. Berdasarkan hasil analisis pada fase preliminary research, dirancang alur belajar stattistika berbasis realistic mathematic education.

Pada fase prototyping stage, prototipe yang dikembangkan dilakukan evaluasi dengan mengacu pada evalusi formatif. Evalusi formatif yang dilakukan pada prototipe yang sudah dirancang yaitu evalusi diri (self evaluation), validasi oleh pakar (expert review) yang dilakukan oleh tiga orang dosen Matematika, satu orang dosen Bahasa Indonesia, dan satu orang dosen Teknologi Pendidikan. Setelah produk yang dikembangkan dinyatakan valid, selanjutnya dilakukan evaluasi per orang (one to one) dan evalusi kelompok kecil (small grup) untuk melihat kepraktisannya. Subjek uji coba pada penlitian ini yaitu 9 orang peserta didik kelas VIII SMPN 2 Siak.

Data penelitian dikumpulkan melalui lembar validasi yang digunakan untuk melihat kelayakan instrument dan produk yang dinilai oleh pakar pada tahap expert review, lembar angket respon guru dan peserta didik digunakan untuk melihat kepraktisan produk yang diuji cobakan pada tahap one to one dan small group, lembar observasi keterlaksanaan desain pembelajaran digunakan untuk melihat keterlaksanaan proses pembelajaran yang menggunakan buku guru dan buku peserta didik berbasis realistic mathematic education (RME), lembar wawancara digunakan untuk meminta pendapat peserta didik terhadap buku 
peserta didik pada tahap one to one dan small group. Data hasil wawancara ini dideskripsikan untuk merevisi, buku peserta didik yang dikembangkan, dan tes kemampuan penalaran matematis peserta didik digunakan untuk melihat pengaruh buku yang diujicobakan terhadap kemampuan penalaran peserta didik.

Adapun kategori validitas produk desain pembelajaran dapat dilihat pada Tabel 1.

Tabel 1. Kriteria validitas

\begin{tabular}{cc}
\hline Rata-rata & Kriteria \\
\hline $\mathrm{R}>3,20$ & Sangat valid \\
$2,40<\mathrm{R} \leq 3,20$ & Valid \\
$1,60<\mathrm{R} \leq 2,40$ & Cukup Valid \\
$0,80<\mathrm{R} \leq 1,60$ & Kurang Valid \\
$\mathrm{R} \leq 0,80$ & Tidak valid \\
\hline
\end{tabular}

Adapun kategori praktikalitas produk desain pembelajaran dapat dilihat pada Tabel 2 .

Tabel 2. Kriteria kepraktisan

\begin{tabular}{cc}
\hline Nilai Kepraktisan (\%) & Kriteria \\
\hline $85 \leq \mathrm{P} \leq 100$ & Sangat Praktis \\
$75 \leq \mathrm{P}<85$ & Praktis \\
$60 \leq \mathrm{P}<75$ & Cukup Praktis \\
$55 \leq \mathrm{P}<60$ & Kurang Praktis \\
$0 \leq \mathrm{P}<55$ & Tidak Praktis \\
\hline
\end{tabular}

\section{HASIL DAN PEMBAHASAN}

\section{Investigasi awal}

Penelitian diawali dengan analisis pendahuluan. Pada tahap ini dilakukan analisis kebutuhan, analisis kurikulum, analisis konsep, analisis peserta didik dan analisis riviu literatur. Berdasarkan analisis pendahuluan tersebut dirancanglah desain pembelajaran statistika berbasis RME untuk meningkatkan kemampuan penalaran matematis peserta didik kelas VIII SMP.

\section{Desain Prototipe}

a. Perancangan Hypotetical Learning Trajectory

Pada tahap ini dirancang HLT yang difokuskan pada materi statistika untuk mengembangankan kemampuan penalaran peserta didik kelas VIII SMP. HLT ini didesain mengadopsi HLT (Simon, 1995) yang terdiri dari tiga bagian yaitu; tujuan pembelajaran, aktivitas pembelajaran dan konteks yang digunakan dalam proses pembelajaran, konjektur tentang bagaimana pemahaman dan strategi peserta didik. Alur pembelajaran yang dirancang terdiri dari 5 HLT yang terdiri dari modus, mean, median, statistik lima serangkai, dan penyebaran data seperti pada Gambar 1.

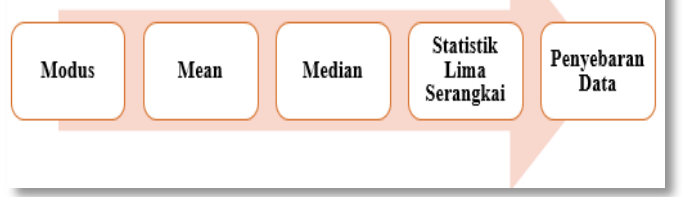

Gambar 1. Rasional HLT

Pertama, menemukan konsep modus melalui aktivitas 1.1 ukuran baju yang paling banyak dipakai oleh peserta didik. Pemilihan aktivitas ini karena modus merupakan data yang paling sering muncul atau paling banyak digunakan, sehingga dari aktivitas tersebut peserta didik dapat mengenal modus dari representasi data.

Kedua, menemukan konsep mean melalui aktivitas 2.1 membagi buah rambutan dengan adil. Macross \& Russel (1995), menyatakan bahwa mean merupakan fair share and balance, sehingga untuk menemukan konsep mean secara informal dapat dengan cara membagi dengan adil atau sama rata. Permasalahan selanjutnya yang terdapat pada aktivitas 2.2 yaitu menemukan sifat rata-rata jika setiap data bertambah, berkurang, dikali, dibagi, 
dengan cara membandingkan nilai ratarata sebelun dengan nilai rata-rata sesudahnya. Sehingga peserta didik dapat menyimpulkan sifat rata-rata dari permasalahan yang diberikan.

Ketiga, menemukan konsep median untuk data ganjil melalui aktivitas 3.1 umur anak yang barada pada urutan yang paling tengah. Selanjutnya menentukan median untuk data genap melalui aktivitas 3.2 dari urutan barisan anggota pramuka. Dari kedua aktivitas tersebut peserta didik distimulus untuk menentukan konsep median sebagai data yang terdapat di paling tengah dari data yang telah diurutkan dari urutan yang peling kecil hingga paling besar.

Keempat, menemukan konsep statistika lima serangkai melalui aktivitas 4.1 keuntungan toko yang memiliki 16 cabang. Masalah ini dihadirkan dengan tujuan untuk menstimulir peserta didik menemukan konsep data terkecil, data terbesar, jangkauan (range), kuartil bawah, kuartil tengah, kuartil atas, dan jangkauan interkuartil.

Kelima, mengeksplorasi modus, mean, dan median dalam mengambil keputusan. Masalah yang diambil yaitu dalam menentukan juara umum pada suatu class meeting. Masalah tersebut bertujuan agar peserta didik dapat mengambil keputusan dari ukuran pemusatan data.

\section{b. Perancangan Buku Guru dan Buku Peserta Didik}

Buku guru dan buku peserta didik yang dikembangkan mengadopsi penulisan buku dari diknas. Buku guru berbasisi RME memiliki beberapa komponen yaitu tujuan pembelajaran, alokasi waktu, tentang matematika, ringkasan, permasalahan kontekstual, rencana penilaian kemampuan peserta didik, prediksi jawaban peserta didik, dan antisipasi guru. Sedangkan buku peserta didik memiliki komponen yaitu tujuan pembelajaran, aktivitas peserta didik, permasalahan kontekstual, dan uji pemahaman.

Selanjutnya dilakukan tahap self evaluation terhadap HLT, buku guru, buku peserta didik. self evaluation merupakan evalusi yang dilakukan sendiri. Kegiatan yang dilakukan pada tahap ini dengan cara melihat kesalahan pengetikan, kalimat yang tidak jelas maknanya, kesalahan tanda baca, pemilihan warna dan ukuran huruf yang tepat. Misalnya pada HLT kesalahan terjadi pada kata "orang" ditulis "oarang", kesalahan pada penulisan nama orang. Pada buku guru dan buku peserta didik warna yang digunakan kurang tepat, sehingga tulisannya menjadi kurang jelas dibaca. Setelah dilakukan evaluasi diri sendiri terhadap desain pembelajaran berbasis RME yang dirancang selanjutnya dilakukan validasi.

Pada tahap validasi dilakukan oleh 5 pakar ahli yaitu, 3 dosen matematika, 1 dosen Bahasa Indonesia, dan 1 dosen teknologi pendidikan.

Pada HLT aspek yang dinilai dalam validasi yaitu aspek isi dan bahasa. Berdasarkan validasi dengan pakar dapat dilihat hasil validasi HLT pada Tabel 3.

Tabel 3. Hasil validasi HLT

\begin{tabular}{cccc}
\hline No & $\begin{array}{c}\text { Aspek Yang } \\
\text { Dinilai }\end{array}$ & $\begin{array}{c}\text { Rata- } \\
\text { rata }\end{array}$ & Kategori \\
\hline 1 & Isi & 3,31 & Sangat Valid \\
2 & Bahasa & 3,11 & Valid \\
\hline
\end{tabular}

Validasi keseluruhan 3,26 Sangat Valid

Berdasarkan hasil yang ditunjukkan oleh Tabel 3, disimpulkan bahwa HLT telah valid dan layak untuk diuji cobakan kepada peserta didik. 
HLT topik statistika yang di implementasikan ke dalam buku guru dan buku peserta didik juga divalidasi. Pada buku guru aspek yang dinilai yaitu aspek isi, Bahasa, ditaktik atau penyajian, dan aspek kegrafikan atau tampilan. Hasil validasi pada buku guru dan buku peserta didik dapat dilihat pada Tabel 4 dan Tabel 5.

Tabel 4. Validasi buku guru

\begin{tabular}{clcc}
\hline No & $\begin{array}{l}\text { Aspek Yang } \\
\text { Dinilai }\end{array}$ & $\begin{array}{c}\text { Rata- } \\
\text { rata }\end{array}$ & Kategori \\
\hline 1 & Isi & 3,28 & Sangat Valid \\
2 & Bahasa & 3,45 & $\begin{array}{l}\text { Sangat Valid } \\
3\end{array}$ \\
$\begin{array}{l}\text { Didaktik atau } \\
\text { penyajian }\end{array}$ & 3,5 & Sangat Valid \\
4 & $\begin{array}{l}\text { Kegrafikan } \\
\text { atau tampilan }\end{array}$ & 3,18 & Valid \\
\hline & Rata-rata & $\mathbf{3 , 3 2}$ & Sangat Valid \\
\hline
\end{tabular}

Tabel 5. Validasi buku peserta didik

\begin{tabular}{clcc}
\hline No & $\begin{array}{c}\text { Aspek Yang } \\
\text { Dinilai }\end{array}$ & $\begin{array}{c}\text { Rata- } \\
\text { rata }\end{array}$ & Kategori \\
\hline 1 & Isi & 3,17 & Valid \\
2 & Bahasa & 3,4 & Sangat Valid \\
3 & Didaktik atau & 3,5 & Sangat Valid \\
& penyajian & & \\
4 & Kegrafikan & 3,17 & Valid \\
& atau tampilan & & \\
\hline & Rata-rata & $\mathbf{3 , 2 8}$ & Sangat Valid \\
\hline
\end{tabular}

Dari Tabel 4 dan Tabel 5 terlihat bahwa hasil validasi buku guru dan buku peserta didik berbasis RME sudah valid dengan kategori sangat valid. Dengan demikian buku guru dan buku peserta didik topik statistika berbasis RME layak untuk diuji cobakan.

Setelah semua produk yang dikembangkan dinyatakan valid, selajutnya dilakukan evalusi perorangan (one to one evaluation) yang dilakukan pada tiga orang peserta didik kelas VIII SMPN 2 Siak dengan kemampuan tinggi, sedang, dan rendah. One to one dilaksanakan selama lima hari dengan satu pertemuan setiap harinya. Selama one to one dilihat proses alur berpikir peserta didik dalam menemukan konsep statistika dengan menggunakan buku peserta didik berbasis RME yang sudah dirancang. Pada pelaksanaan one to one juga dilihat kendala-kendala yang dihadapi peserta didik apakah permasalahan yang diberikan mudah dipahami, seperti yang terdapat pada Gambar 2.

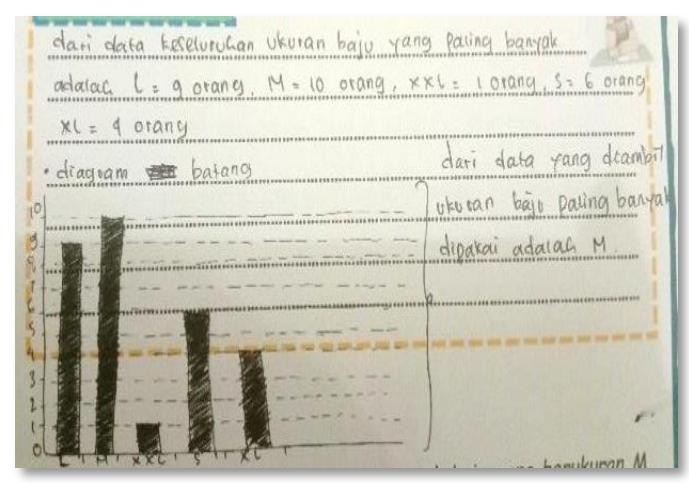

Gambar 2. Contoh jawaban peserta didik saat one to one evaluation

Pada Gambar 2 peserta didik diminta untuk menentukan konsep modus yang terdapat pada aktivitas 1.1 pada buku peserta didik berbasis RME. Peserta didik mampu menyelesaikan permasalahan dan menentukan konsep dari modus yaitu data yang paling sering muncul atau dengan frekuensi tertinggi. Kendala dalam menyelesaikan aktivitas 1.1 peserta didik sedikit ragu dalam mengelompokkan gender yang diberikan pada soal, sehingga peserta didik keliru dalam mengelompokkan ke kategori laki-laki atau perempuan.

Selanjutnya peserta didik diminta untuk memberikan tanggapannya terhadap buku peserta didik yang telah digunakan untuk melihat praktikalitas dari suatu produk yang dirancang. Pada tahap one to one angket diberikan kepada tiga orang peserta didik. Hasil dari angket praktikalitas buku peserta didik pada one to one dapat dilihat pada Tabel 6. 
DOI: https://doi.org/10.24127/ajpm.v10i4.4362

Tabel 6. Praktikalitas buku peserta didik pada one to one

\begin{tabular}{clcc}
\hline No & $\begin{array}{c}\text { Aspek Yang } \\
\text { Dinilai }\end{array}$ & $\begin{array}{c}\text { Rata- } \\
\text { rata }\end{array}$ & Kategori \\
\hline 1 & $\begin{array}{l}\text { Kemudahan } \\
\text { Penggunaan }\end{array}$ & 83,3 & Praktis \\
& Pengun & & \\
& Efisiensi & 91,67 & Sangat Praktis \\
& Waktu & & \\
3 & Daya Tarik & 80,6 & Praktis \\
4 & Kemudahan & 77,1 & Praktis \\
5 & Manfaat & 86,7 & Sangat Praktis \\
\hline Nilai Praktikalitas & $\mathbf{8 2 , 8}$ & Praktis \\
\hline
\end{tabular}

Setelah dilakukan revisi terhadap hasil one to one evaluation, selanjutnya dilakukan evaluasi kelompok kecil (small group). Evaluasi kelompok kecil dilakukan pada 6 orang peserta didik kelas VIII SMPN 2 Siak yang berkemampuan tinggi, sedang, dan rendah. Small group dilakukan selama 5 kali pertemuan dengan melihat alur berpikir peserta didik dalam menemukan konsep statistika melalui buku peserta didik yang berbasis RME.

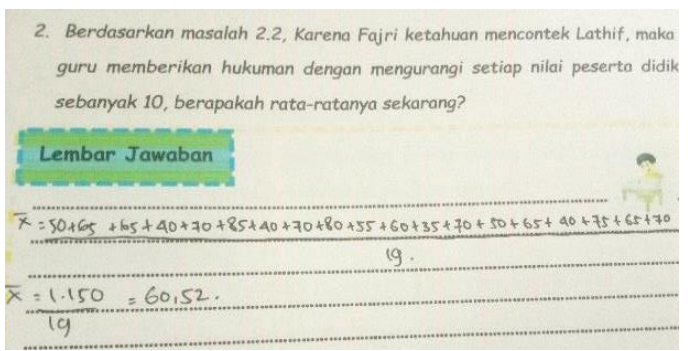

(a)

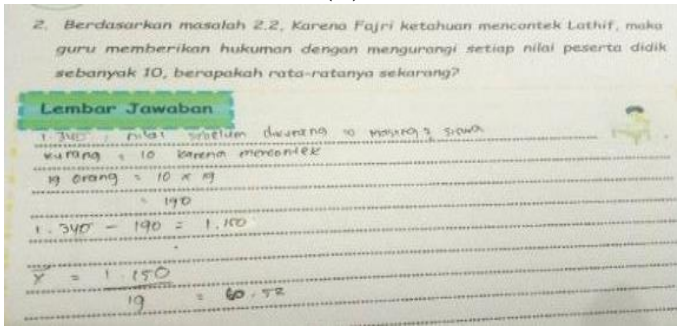

(b)

Gambar 3. Contoh jawaban peserta didik saat small group

Gambar 3 merupakan salah satu jawaban dari aktivitas-aktivitas yang diberikan dalam buku peserta didik berbasis RME dalam menemukan konsep statistika pada saat small group evaluation. Gambar 3 merupakan jawaban peserta didik dalam menemukan rata-rata berdasarkan sifatsifatnya. Pada permasalahan yang diberikan peserta didik menentukan nilai rata-rata dari masing-masing data yang telah dikurangi. Dari dua kelompok yang terdapat pada small group, peserta didik mampu menyelesaikan permasalahan tersebut dengan dua cara yang berbeda dengan jawaban yang benar.

Selanjutnya diberikan angket praktikalitas untuk melihat kemudahan dalam menggunakan buku guru dan buku peserta didik pada tahap small group. Angket respon guru diberikan kepada 2 orang guru matematika yang mengajar topik statistika. Pemberian angket kepada 2 orang guru dikarenakan tidak dilakukannya field test. Selanjutnya dilakukan penyebaran angket respon peserta didik terhadap buku peserta didik yang telah digunakan. Pendataan dilakukan guna untuk melihat praktikalitas dari buku peserta didik yang telah dirancang pada tahap small group evaluation. Hasil dari praktikalitas buku guru dan buku peserta didik dapat dilihat pada Tabel 7 dan Tabel 8.

Tabel 7. Praktikalitas terhadap buku guru

\begin{tabular}{clcc}
\hline No & $\begin{array}{c}\text { Aspek Yang } \\
\text { Dinilai }\end{array}$ & $\begin{array}{c}\text { Rata- } \\
\text { Rata }\end{array}$ & Kategori \\
\hline 1 & $\begin{array}{l}\text { Kemudahan } \\
\text { Penggunaan }\end{array}$ & 95,80 & Sangat Praktis \\
& & \\
2 & Efisiensi & 81,30 & Praktis \\
& Waktu & & \\
3 & Daya Tarik & 91,70 & Sangat Praktis \\
4 & Kemudahan & 84,40 & Praktis \\
5 & Ekivalensi & 87,50 & Sangat Praktis \\
\hline Nilai Praktikalitas & $\mathbf{8 8 , 3 0}$ & Sangat Praktis \\
\hline
\end{tabular}


DOI: https://doi.org/10.24127/ajpm.v10i4.4362

Tabel 8. Praktikalitas buku peserta didik pada small group

\begin{tabular}{clcc} 
No & $\begin{array}{c}\text { Aspek Yang } \\
\text { Dinilai }\end{array}$ & $\begin{array}{c}\text { Rata- } \\
\text { Rata }\end{array}$ & Kategori \\
\hline 1 & $\begin{array}{l}\text { Kemudahan } \\
\text { Penggunaan }\end{array}$ & 93,10 & Sangat Praktis \\
& Efisiensi & 87,50 & Praktis \\
2 & Waktu & & \\
3 & Daya Tarik & 88,90 & Sangat Praktis \\
4 & Kemudahan & 82,30 & Praktis \\
5 & Manfaat & 88,30 & Sangat Praktis \\
\hline Nilai Praktikalitas & $\mathbf{8 7 , 8 0}$ & Sangat Praktis \\
\hline
\end{tabular}

Berdasarkan Tabel 7 dan Tabel 8 nilai kepraktisan desain pembelajaran statistika berbasis RME yang diperoleh dari angket dengan kategori sangat praktis. Berdasarkan hasil ini maka dapat disimpulkan bahwa buku guru dan buku peserta didik topik statistika berbasis realistic mathematic education (RME) dapat dengan mudah digunakan sesuai dengan langkah-langkah yang telah dirancang.

Hal ini sesuai dengan hasil penelitian (Afriadi, 2019), (S. K. Sari, 2017) bahwa desain pembelajaran statistika yang berbasis RME dapat meningkatkan kemampuan penalaran peserta didik, serta dengan menggunakan RME peserta didik dapat mengenal matematika secara realistik. Hasil penelitian lain juga menunjukkan Alur pembelajaran yang memenuhi prinsip-prinsip pendekatan RME pada alur belajar ini menekankan pada penyelesaian secara informal. Hal ini dilakukan untuk memanfaatkan pengetahuan awal dan pengalaman siswa yang telah diperoleh dalam kehidupannya.

\section{KESIMPULAN DAN SARAN}

Berdasarkan hasil analisis data yang telah dilakukan dapat disimpulkan desain pembelajaran statistika berbasis realistic mathematic education (RME) untuk meningkatkan kemampuan penalaran matematis peserta didik kelas VIII SMP yang diimplementasikan kedalam buku guru dan buku peserta didik telah valid dan praktis. Berdasarkan hasil di atas, maka disimpulkan desain pembelajaran statistika kelas VIII SMP dapat dijadikan sebagai pedoman bagi guru dalam melaksanakan pembelajaran. Untuk peneliti selanjutnya disarankan untuk melakukan ujicoba lanjutan di sekolah lain untuk melihat praktikalitas dan efektivitas yang lebih luas terhadap desain pembelajaran yang telah dikembangkan.

\section{DAFTAR PUSTAKA}

Afriadi, J. (2019). Pengembangan Desain Pembelajaran Topik RataRata Hitung Berbasis Realistic Mathematics Education (RME) di Kelas IX SMP/MTs. Math Educa Journal, 2(1), 91-102. https://doi.org/10.15548/mej.v2i1. 179

Andrews-Larson, C., Wawro, M., \& Zandieh, M. (2017). A hypothetical learning trajectory for conceptualizing matrices as linear transformations.

International Journal of Mathematical Education in Science and Technology, 48(6), 809-829.

https://doi.org/10.1080/0020739X .2016 .1276225

Cárcamo Bahamonde, A. D., Fortuny Aymemí, J. M., \& Gómez i Urgellés, J. V. (2017). Mathematical modelling and the learning trajectory: tools to support the teaching of linear algebra. International Journal of Mathematical Education in Science and Technology, 48(3), 338-352. 
DOI: https://doi.org/10.24127/ajpm.v10i4.4362

https://doi.org/10.1080/0020739X .2016 .1241436

Daro, P., Mosher, F. A., \& Corcoran, T. (2011). Learning Trajectories in Mathematics Education: A Foundation for Standards, Curriculum, Assessment, and Instruction. CPRE Research Report \#RR-68, 81-89. http://dx.doi.org/10.1207/s153278 33mt10602_1

Dewi, D. K., Khodijah, S. S., \& Zanthy, L. S. (2020). Analisis Kesulitan Matematik Siswa SMP pada Materi Statistika. Jurnal Cendekia: Jurnal Pendidikan Matematika, 4(1), 1-7. https://doi.org/10.31004/cendekia. v4i1.148

Fauzan, A., \& Yerizon, Y. (2013). Pengaruh Pendekatan RME dan Kemandirian Belajar Terhadap Kemamampuan Matematis Siswa. Prosiding SEMIRATA 2013, 1(1).

Gravemeijer, K. (2010). A decade of PMRI in Indonesia. Tenbrink Utrecht.

Laurens, T., Batlolona, F. A., Batlolona, J. R., \& Leasa, M. (2017). How does realistic mathematics education (RME) improve students' mathematics cognitive achievement? Eurasia Journal of Mathematics, Science and Technology Education, 14(2), 569-578.

Maryati, I. (2017). Peningkatan Kemampuan Penalaran Statistis Siswa Sekolah Menengah Pertama Melalui Pembelajaran Kontekstual. 6, 129-140.

Maryati, I., \& Nanang Priatna. (2017). Analisis Kesulitan Dalam Materi Statistika Ditinjau Dari Kemampuan Penalaran Dan Komunikasi Statistis. Prisma, 6(2), 173-179. https://doi.org/10.35194/jp.v6i2.2 09

Masthura, L., Salasi, R., \& Zaura, B. (2016). Penerapan Metode Drill pada Materi Statistika Kelas VII SMP Negeri 10 Banda Aceh Tahun Pelajaran 2015 / 2016. Jurnal Ilmiah Mahasiswa Pendidikan Matematika, 1(1), 8697.

Mullis, I. V. S., Martin, M. O., Foy, P., \& Arora, A. (2012). TIMSS 2011 international results in mathematics. ERIC.

Nisa, S., Zulkardi, Z., \& Susanti, E. (2019). Kemampuan Penalaran Statistis Siswa Pada Materi Penyajian Data Histogram Melalui Pembelajaran Pmri. Jurnal Pendidikan Matematika, 13(1), 21-40. https://doi.org/10.22342/jpm.13.1. 5460.21-40

OECD. (2015). PISA 2015 Results in Focus. OECD , 1-31.

Rangkuti, A. N. (2015). Pengembangan Alur Pembelajaran Topik Pecahan di Sekolah Dasar dengan Pendekatan Pendidikan Matematika Realistik. Padang: Program Pascasarjana UNP.

Sari, R. M., Amir M.Z., Z., \& Risnawati, R. (2017). Pengembangan Lembar Kerja Siswa (LKS) Berbasis Pendekatan Realistic Mathematic Education (RME) Untuk Memfasilitasi Kemampuan Representasi Matematis Siswa SMP. Formatif: Jurnal Ilmiah Pendidikan MIPA, 7(1), 66-74. https://doi.org/10.30998/formatif. v7i1.1108

Sari, S. K. (2017). Pengembangan Desain Pembelajaran Statistika Berbasis IT Menggunakan Pendekatan Realistic Mathematics 
DOI: https://doi.org/10.24127/ajpm.v10i4.4362

Education untuk Kelas VIII SMP. JNPM (Jurnal Nasional Pendidikan Matematika), 1(2), 290.

https://doi.org/10.33603/jnpm.v1i 2.495

Smith, J. P., Vogeli, B. R., Walker, E., \& Wasserman, N. H. (2011). Design Research in the Netherlands: Introducing Logarithms Using Realistic Mathematics Education. Journal of Mathematics Education at Teachers College, 2(1), 47-52. https://doi.org/10.7916/jmetc.v2i1 .708

Stacey, K. (2011). The PISA view of mathematical literacy in Indonesia. Journal on Mathematics Education, 2(2), 95126.

https://doi.org/10.22342/jme.2.2.7 46.95-126

Wijaya, A. (2012). Pendidikan Matematika Realistik, Suatu Alternatif Pendekatan Pembelajaran Matematika. Yogyakarta: Graha Ilmu. 